\title{
THE SPATIAL CONCEPTS OF CULTURAL HERITAGE VILLAGE TOWARD A TOURISM DEVELOPMENT; A CASE STUDY OF KADILANGU DEMAK INDONESIA
}

\author{
Atiek SUPRAPTI*, Agung Budi SARDJONO, Indriastjario INDRIASTJARIO, \\ Edward E. PANDELAKI \\ Department of Architecture, Faculty of Engineering, Diponegoro University, \\ Tembalang 50273 Semarang Indonesia
}

Received 12 October 2018; accepted 13 February 2019

\begin{abstract}
Globalization perspective considers the world as a large market, which requires the resources readiness as capital to be able to participate actively. Local culture is an important capital to create identity and social harmonization in constructing a better quality of life. In the 15th-16th century AD, the Java north coast of Indonesia was known for having several old towns with their important roles in spreading Islam. Centuries later the legend of Walisanga still greatly influences the people's lives particularly in Demak. The Muslim community is living tradition in this area has become one of the identity of the city. The development in the last decades has shown significant impacts on the tourism sector. This phenomenon showed that there would be conflicts of interests between social-cultural sectors and economic sectors. In this kind of situation, the community must adapt spatial settings to accommodate their needs. The purpose of this article is to find the concept of spatial setting formed by economic, cultural and religious factors in this historical area. The locus is the Muslim settlements in Kadilangu Demak a site of Sunan Kalijaga's heritage. This study that employed qualitative research methods, the three spatial concepts proposed are: (1) the identity space of local culture is strongly exists (2) the shift in the value of space, which has changed from the glory of the noble family tothe common people (3) the space for morality control, which functions as the control of community's moral. The third concepts are local genius, which is significantly potential for tourism.
\end{abstract}

Keywords: cultural heritage, spatial setting, tourism, Kadilangu.

\section{Introduction}

In the $11^{\text {th }}$ to $16^{\text {th }}$ centuries north coast of Java Island became an entrance gate for Islam to Java (Wertheim, 1999). One of the significant influences was the Islamic teaching brought by merchants from India, Persia, and China. The phenomenal story was seen from the Walisanga's role in the process of Islamic propaganda. Walisanga is an Islamic religious proselytism institution consisted of nine trustees who were working during the initial period of Islamic entry to Java Island in the middle of $15^{\text {th }}$ to $16^{\text {th }}$ century. In this history, Demak was an important location (Wertheim, 1999; Tjandrasasmita, 2000; Lombard, 2005; Qurtuby, 2003). This effort reached its heyday with the establishment of the Demak Sultanate in the Central Java in 1475. In this period the spread of Islam developed smoothly and rapidly supported by Walisanga with Sunan Kalijaga as one of the figures. As a reward of this success, Sultan of Demak gifted him with a land of perdikan (the land was exempted from taxes as the result of bearing some burdens or responsibilities) in Kadilangu district.

Acculturation of Islamic teaching and Hindu culture enrich the Islamic teachings that has finally become the character of Javanese Islam (Qurtuby, 2003). Moslem settlement was marked by the existence of these functions: houses, markets, madrasah, and mosques (Ekomadyo, 1999). The people living in coastal area were very open to outsiders and very familiar to the trading activities that improved the economic condition (Suprapti et al., 2010, 2016). This settlement is a cultural heritage that is important to be conserved since it contains values of local culture. The setting system along with organization of space, time, meaning, communication, cultural landscape and physical elements are determining elements

*Corresponding author. E-mail: atiekbudiarto@gmail.com 
in a settlement (Rapoport, 2005). Furthermore, there is a reciprocal relationship between the setting system and humans living inside.

Adaptation is an adjustment process toward natural/ human system with the new environment. In this case, an adjustment aims to avoid hazards and to receive benefits from an opportunity (IPCC, 2014; Laukonnen et al., 2009; National Research Council, 2010). A five-century heritage village against the environmental change makes adaptation in the form of a series of change and transformation, so it can survive in social life. The development of tourism village requires the involvement of several stakeholder's namely the government, private sectors and community members (Amerta, 2017). Cultural heritage is the village development in the form of integration among attractions, accommodations, and supporting facilities presented in the community life structure (Dewi, 2017). A cultural village should meet at least some of the following requirements: good accessibility, some interesting objects, community and officials supports, security, adequate accommodation, and related objects already known by public (Syafi'i et al., 2015). In developing countries, the spatial change of cities will influence people's economic and social structure (Santoso, 2013; Zahnd, 2006). This kind of change is mostly caused by capitalization-modernization pressure (Ishomuddin, 2005). The spatial change in a heritage area should conserve the local identity and social harmony. It was influenced by the change of functions, needs, economy, social life (Habraken et al., 1976; Rapoport, 1969, 1990; Rossi \& Eisenman, 1982), activity and life style (Higgins, 2014; Marlina, 2017). The residential change due to the informal economic factor has successfully improved the life quality (Dundar, 2001; Lawanson et al., 2012; Keller, 2002). It is important to discover the emergence of conflict of interests regarding the economic tourism pressures in Kadilangu since this area has experienced changes for three periods: (1) a period of Perdikan land status before 1970, where the Sunan Kalijaga's family had significant influence, (2) after Perdikan land status (1970-1999), and (3) reformation period (1999-now).

\section{Methods}

The research was located in Kadilangu Demak of Central Java Province, Indonesia (see Figure 1). The data needed are as primary and secondary. Primary data included physical data, such as buildings and environment, spatial elements, and non-physical data such as culture, ideology, spiritual perspective, and social system related to the space arrangement. Spatial and building architecture data were compiled through measurement, documentation, and sketches. Interviews were conducted with various members of the society: children, teenagers, housewives, heads of households, public figures, religious teachers (ustadz), religious leaders, and others. The following are the stages in this study:

- Preparation Stage. It consisted of (1) theoretical study as the background knowledge; (2) the formulation of research method, the inductive approach that raised two local concepts; (3) preparation of research tools and equipment.

- Field Survey Stages. It consisted of (1) grand tour and (2) mini tour.

- Grand Tours is an observation conducted in the entire research area to obtain an early image of the condition of research area as a whole. Participative observation was carried out and documented in notes, diagrams, photos, sketches, maps, and other media, as well as physical data of buildings and building groups. Mini tour included in-depth observation with documentations of the phenomena in the field. There were five steps of mini tour (Spradley, 1997). The first one was the domain analysis to find the types of domains, analyze and then explore them to

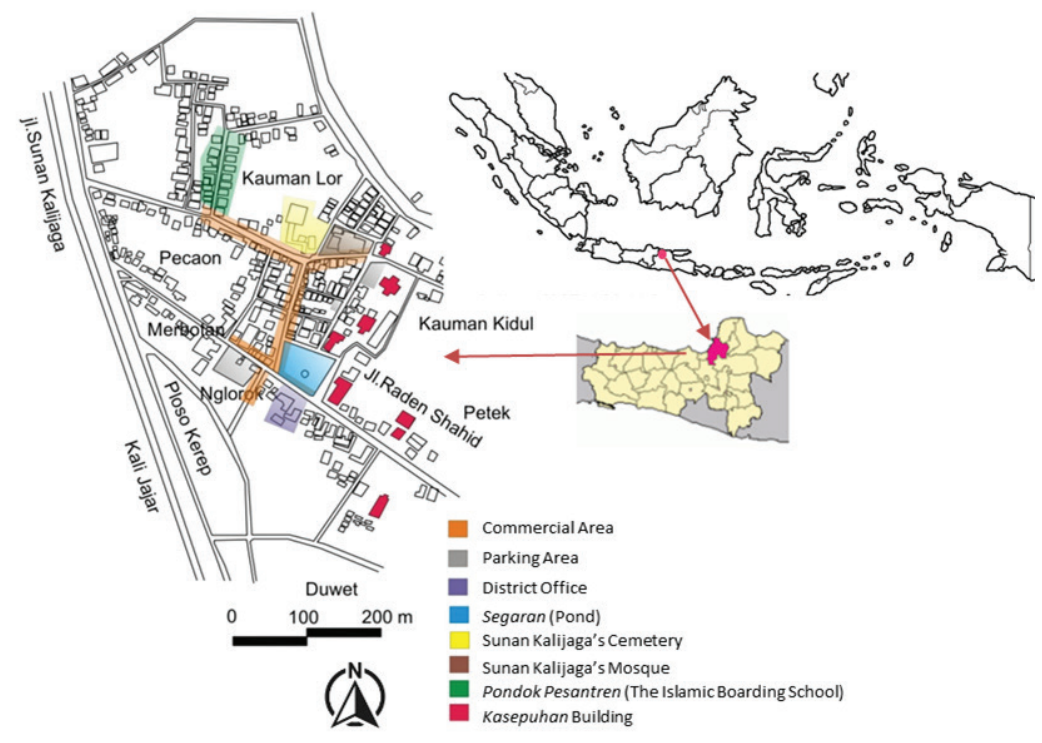

Figure 1. Research location of Kadilangu, Demak (source: processed from Bappeda Demak, 2015) 
find influential domains. The second one was focused observation to the domains. The third one was the analysis of taxonomic which would direct it to the internal structure of each domain. This step aimed to find principles of the arrangement of original spatial symbols in the domain. The fourth step was componential analysis that was carried out by looking for meanings through observation on how symbols were connected. The fifth step was determining themes where each theme has four criteria: measurable, logical, emic, and transcendental.

\section{Result and discussion}

\subsection{Cultural heritage village of Sunan Kalijaga}

Kadilangu is a district in Demak regency known for its cultural history with, Sunan Kalijaga which was one of Walisanga figure. Its distance is approximately $2 \mathrm{~km}$ toward the southeast of Demak. The area covers 37.875 square meters and has paddy fields as much as 171 square meters. The population in 2017 was 3573, and $96 \%$ of them were Muslim. Formerly Kadilangu was a settlement of Sunan Kalijaga's descendants in the land of Perdikan. People of Kadilangu are divided into two social statuses: Sunan Kalijaga's descendants and commoners. The main commodities are from agricultural sector, but since 2000, along with the development of the religious tourism people has been starting to switch their jobs intoservice and trading sectors. The structure of spatial setting consists of four elements namely (1) the House of Kasepuhan, (2) The residence for commoners, (3) the Islamic boarding school, (4) The mosque and cemetery.

- The House of Kasepuhan (as the other name is Notobratan) was built in 1514. Its former function was for government center office, but nowadays it becomes a secretarial office and guesthouse since some of descendants have migrated to other cities. The house of Kasepuhan holds annual traditional ceremonies. The head of Kasepuhan has main tasks to coordinate the activities of Sunan Kalijaga's decendants, as well as to take care the cemetery, the mosque, and magersari land (a large land belongs to a nobleman and it was used to reside for the noble family and their servants).

- Residence for commoners spread outside of Kasepuhan house. People's livelihood has changed from agricultures to trading and services in order, to support tourism such as home-stays, souvenir shops, parking areas, and public toilets, also batik crafts stores.

- Pondok Pesantren (the Islamic boarding school) was established in 1881 by local religious leaders with the purpose of teaching Islam to young generation in Kadilangu and its surrounding areas.

- The old mosque founded by Sunan Kalijaga was firstly renovated in 1564. At the backside of the mosque located a cemetery consist of Sunan Kalijaga's family tombs, including his wife, children, and other relatives. There is a sacred well located around the cemetery, which is believed could bring blessings. The cemetery-mosque setting is a concept of the traditional Javanese spatial arrangement (Wiryotomo, 1995), which also can be found in other Javanese old cities like Ampel, Kudus, Demak, Yogjakarta, and Surakarta.

\subsection{Identity space for family dignity}

The space for family dignity is a space for strengthening the relationship of Sunan Kalijaga's kinship. Annually they arrange several traditional ceremonies in which most of family members attend and take a role. The traditional sacred ceremonies aims to commemorate the figure of Sunan for his services in Islamic teaching and for his dedication to the development of the Javanese culture. These ceremonies also could rake up people to be obedient and submissive to the ruler (Koenjtaraningrat, 1983; Moertono, 1985; Moedjanto, 1987; Sutrisno \& Putranto, 2005) hence the dignity of the family is still respected by thousands visitors.

\subsubsection{House of Trah (Clan)}

The Houses of Trah are divided into Kasepuhan and Panembahan.

- Kasepuhan is the symbol of Sunan Kalijaga pedigree. In the period of Demak Sultanate (1500-1546), and Mataram Sultanate (1577-1681) Kasepuhan was the autonomous ruler upon Perdikan of Kadilangu. However, after 1970 Kasepuhan has less function as the institution to manage cultural activities only, in relation to changes of regimes that triggered changes in the spatial function. The changes are regarding to the characteristics of space to be more open. For example, the Pendopo (pavilion) had an original function as a meeting place between the leader of Kadilangu and the subordinates and also the guests in relation to government's power (see Figure 2). Nowadays it functions mainly as a gathering place for other Kasepuhan institutions of Central Java region, a place of discussion for traditional/cultural issues of Sunan's descendants, and a place of election for the head of Kasepuhan. After releasing the status of Perdikan, the kitchen previously separated from the main house is now attached inside it. Water filtering area which was abandoned becomes the warehouse (see Figure 3). In this time Kasepuhan no longer symbolizes political power, but it has shifted into a space of cultural traditions opened to the public.

- Panembahan is the term for direct descendants of Sunan Kalijaga. The institutional system of Panembahan aims at keeping the purity of Sunan's cultural artifacts. The spaces include the private Panembahan house and the office of Panembahan. Related to the Panembahan function, it has changes of relationship from noble landlord-servant relation to common people relationship. 
The Trah of Kadilangu conserves traditional culture such as rituals, customs, and spirituality. From discussion above it shows that the religion aspect is one of the constructing elements (Linton, 1956; Koenjtaraningrat, 1983), which have been strongly developed during five centuries. This phenomenon commonly occurs in the inland of Java. In the areas of noth coast Java like Demak and Kudus, people tend to use the great name of their elders who became the role models and the space identity (Suprapti et al., 2014).

\subsubsection{Hierarchical space}

Generally, the hierarchy of space is divided into two categories: the nobles, and the commoners. Physically the spaces for noble houses are signed with the lavish traditional houses of Joglo Limasan (See Figure 2 and 4), and some of these houses are closed and fenced up. This appearance is the physical shape of the social hierarchy in Kadilangu. The characters of Javanese noble houses appear on the ornaments, the shape of roof, and the natural materials like woods and stones. The noble houses are more complex in the spatial arrangement, because they are the center of this hierarchy. Meanwhile the commoner's houses include sentono (guard faction), merbot (caretaker faction), and magersari (courtiers' faction) that have a simple and humble spatial arrangement, with less ornament, and a gable roof. Commoner houses are open and fenceless. This openness is prone to change. Many traditional houses
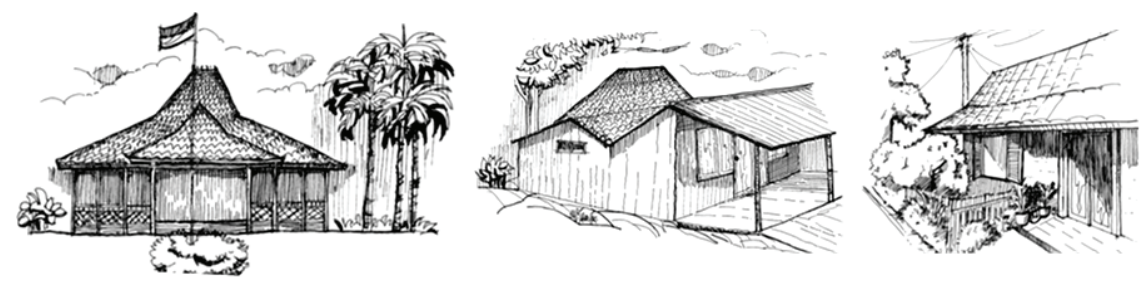

Figure 2. From left to the right: Joglo Pendopo, and the Joglo Limasan houses of Sunan's descendants (source: Survey, 2017)
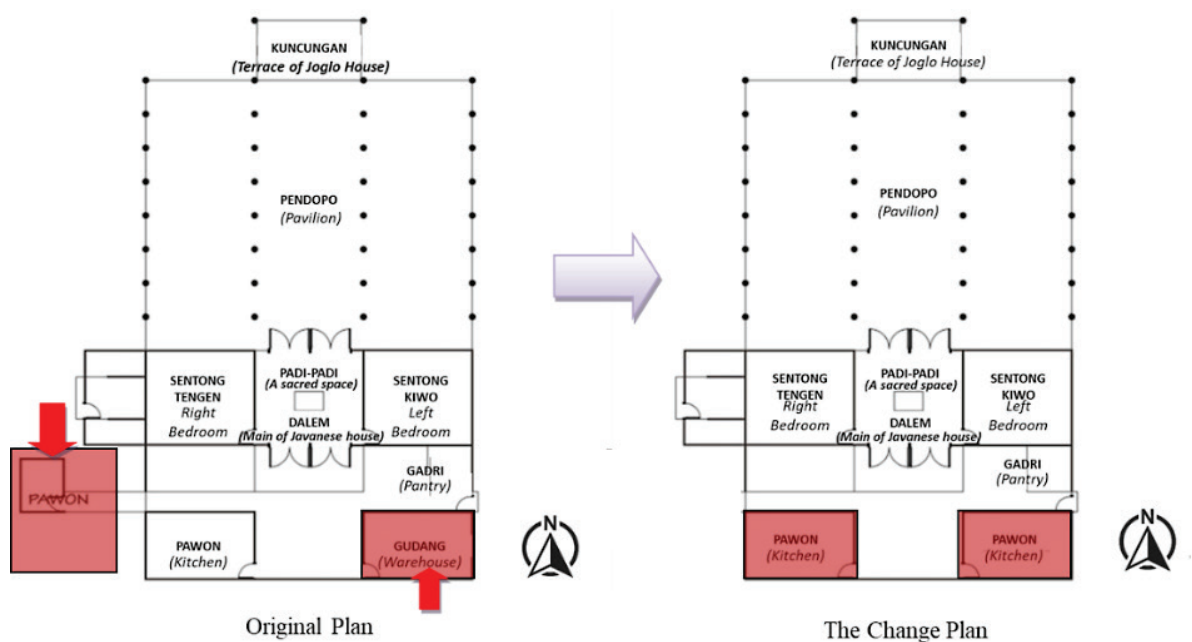

Figure 3. The change plan in Kasepuhan house at Kadilangu (source: Survey, 2017)
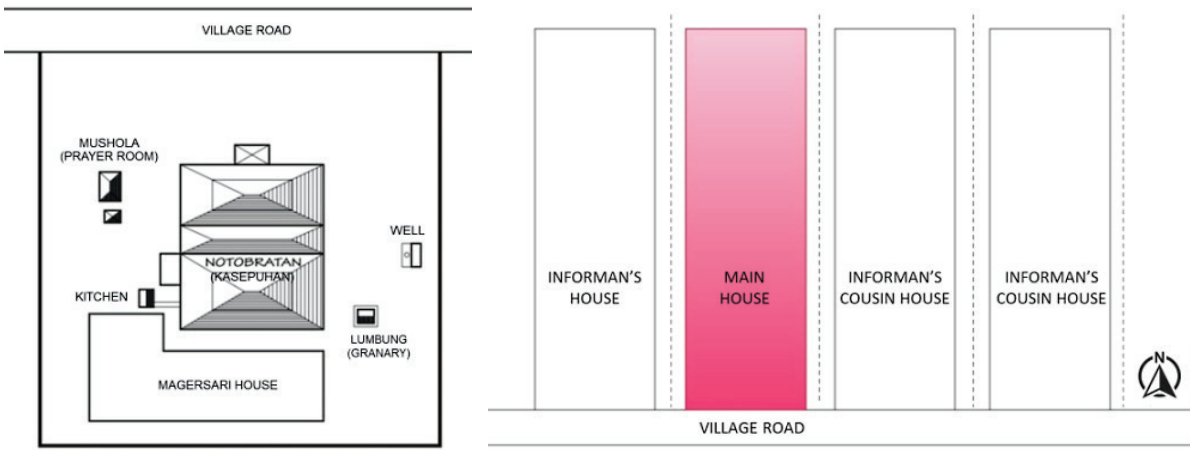

Figure 4. The Joglo Limasan shape with spacious yard and fence is the characteristic of noble houses while the commoners' houses are simple and gable-roofed (source: Survey, 2017) 
were demolished and rebuilt to modern shapes, but they still hold on to the concept of single-story houses to respect Sunan Kalijaga's cemetery.

The hierarchical spaces in Javanese houses can be found in the hinterland areas (the former territory of the Mataram Sultanate) that inherit the primordialism. This condition is quite different from the area of Java north coast. The hierarchical space in Kadilangu maintains aristocracy and its original characteristic. It cannot be found in the locations in the north coast of Java, including Kudus City (Suprapti et al., 2014). The hierarchical arrangement in the cemetery put Sunan Kalijaga's tomb location at the highest level and, the farthest distance from the entrance (see Figure 5). Until nowadays people greatly honor the tomb.

\subsubsection{Sacred space}

Padi-padi is the space inside dalem (the main building of a Javanese house) that functioned as the throne of the head of Perdikan in the past. Inside padi-padi is a chair for him to welcome guests. This throne is called padi-padi, and it is located under a pedestal. Padi-padi means a space to stabilize the fertility of agricultural land, so that the harvest would always be abundant. This pedestal has a strong tie to ancestors. The cone shape is directed to the center point, thus padi-padi has a spatial pattern located in the middle of the room and towards the center (see Figure 6). Hence after the revolution, Perdikan status was revoked, and then the dalem and padi-padi are closed for public and only open for the members of the trah (noble family). This sacred space is full of blessing due to its magical and psychological effects (Agustina et al., 2014). This sacred space has changed from sacred for public to be sacred for private.

\subsubsection{Magersari}

Magersari is the term for commoners who live in the nobleman land. Magersari houses are situated at the rear side of Kasepuhan building (see Figure 7). Dwellers serve descendants of Sunan as courtiers through generations. Several tasks of magersari including gardening, cook-

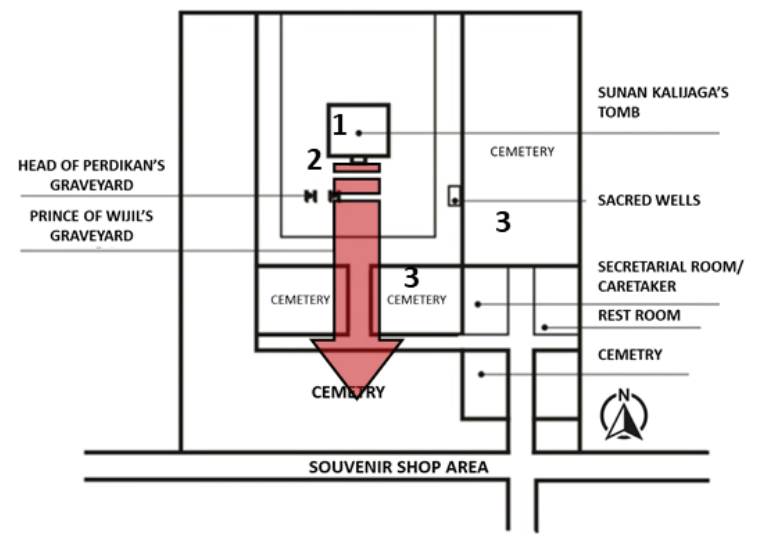

Figure 5. The hierarchical space in Sunan Kalijaga's cemetery (source: Survey, 2017) ing, housekeeping and so on. Kasepuhan and magersari's houses are not separated by fence. The concept of magersari is widely known as the legacy of Javanese aristocratic culture. Generally, inside the complex of Javanese Palace, magersari shows the harmonious relationship between the rulers and people who served them (Setiadi, 2006). The rulers lent the land located close to the palace to be occupied by people who served them. In this way the rulers had an advantage because the servants were always ready to serve them every time, and they would receive the free land to live near their workplace.

\subsubsection{Changing of space function}

\section{Abandon of Fertility Space}

In the past people of Kadilangu district made a certain ritual to hand over the harvests to the ruler of Kasepuhan, then kept them in the granary. The granary is a part of the traditional Javanese house to keep some of harvests,

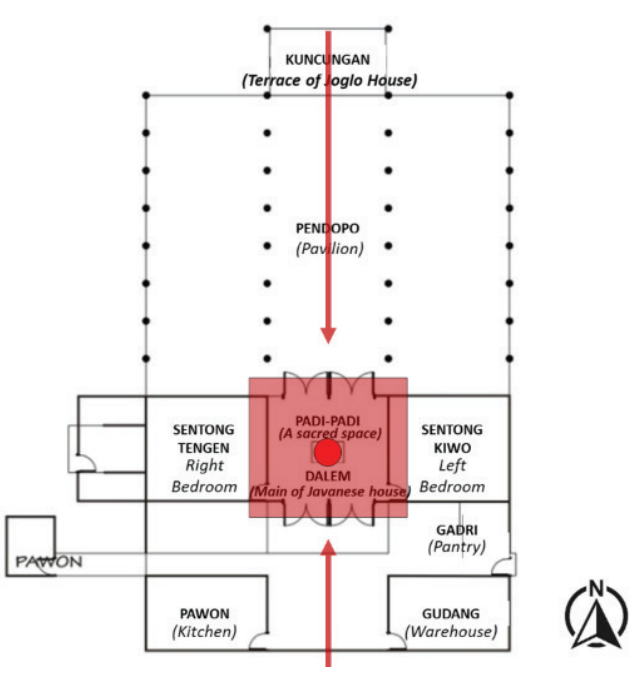

Figure 6. The space of padi-padi representing the sacred space due to the respect to the ancestors and the rulers in the past (source: Survey, 2017)

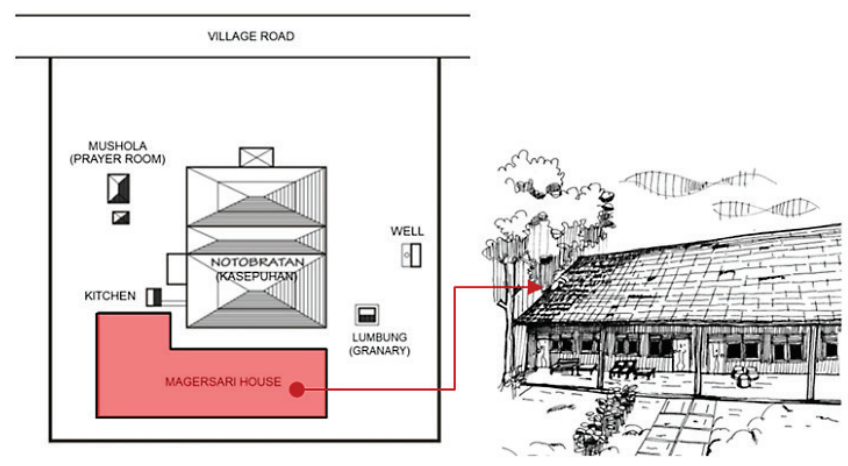

Figure 7. Magersari located behind Kasepuhan house (source: Survey, 2017) 


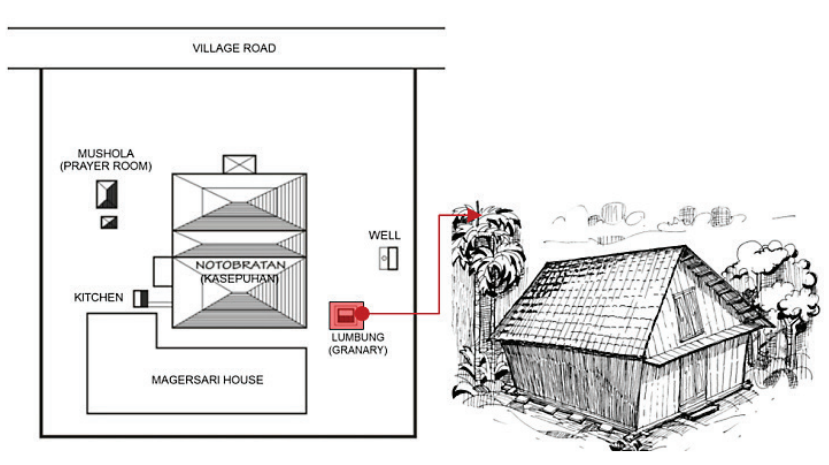

Figure 8 . The granary has changed into a warehouse (source: Survey, 2017)

which has meaning as the fertility - sacred space. The change of occupational pattern from farming to trading influences the function of the granary. Along with the decrease of farming fields and the abolishment of Perdikan land, people have freedom to change and build new spaces (see Figure 8), so that the granary in Kasepuhan has hardly been used anymore. This building has been converted into a warehouse. Now the granary is shifted to be profane space. The change of economic pattern has shifted the cultural orientation.

\section{Strengthening of religiosity}

A former guest house was established next to main building for the ruler's guests. But after the development of modern transportation and the decreases of Kasepuhan's role, this building is no longer used. Then its function is converted into a place to pray (mushola) complete with an ablution area (see Figure 9). This indicates the strengthening of religiosity leaving the aristocratic hierarchical order. Refering to the statement of Rapoport (2000), that the influence of the lifestyle on the social changes appears from shifting of the old cultural values by the strengthening of religious values.

\section{Space for Blessing}

The Pendopo (pavilion) is open for public in certain days, such as the ceremonies of Ruwatan (a traditional Javanese ritual aims to protect communities from threats of calamities and hazards), Jamasan (a traditional Javanese ritual aims to purify the heirlooms), and Sadranan (a traditional Javanese ritual aims to make a pilgrimage to the tombs of ancestors in Ramadhan month), (see Figure 10 and 11). Communities believe that through carrying out the ceremonies, they would be safe and secure, and Sunan's descendants still belong the spiritual powers to lead those ceremonies. The tradition that has been arranged by Kasepuhan contains sanctity in connection with the primordial character building (Agustina et al., 2014). Spaces in Javanese houses and their functions are still conserved, and the strong faith for the blessing and protection of the late Sunan shows that people still honor him. Thousands of people attend the ritual and fight over washing water of the heirlooms. They believe that they will receive blessing from this water. A similar condition can also be found in the other sites of of Walisanga like Sunan Ampel's site in Surabaya where, thousands of pilgrims visit the site to receive blessing from the sacred water every day (Suprapti et al., 2016).

\subsection{Shift in the value of space}

\subsubsection{Shawl house}

Commoners from the faction of sentono or merbot (workers of Kasepuhan) mostly feel at home living around the cemetery. One of the reasons is related to their belief in the blessing of the place through their dedication. The shawl house forms appear in line arranged in some alleys. This is influenced by the system of traditional Javanese land inheritance. The wide land is divided linearly elongated from front side to back side into few sections according to the number of heirs. Furthermore, the heirs built new houses next to the main house and formed the shawl house elongating the site. Physically the houses are

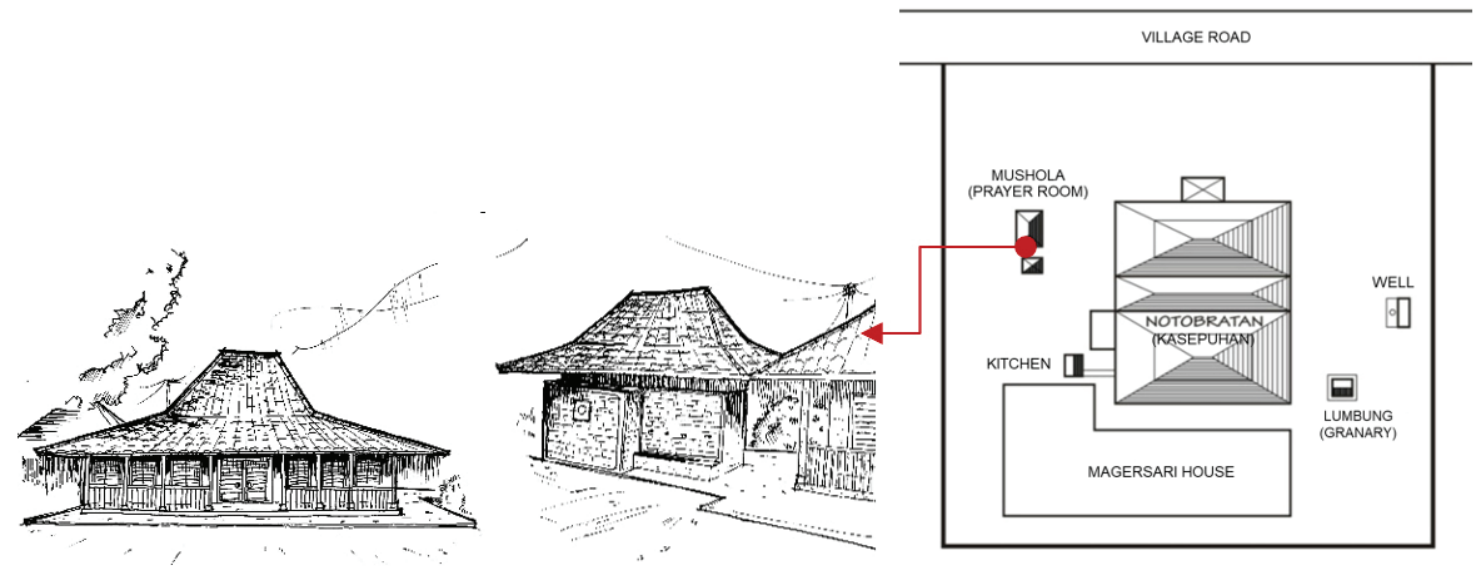

Figure 9. From left to the right: The former function was a guesthouse, but now it is a praying room (mushola); a new ablution place was built to complete the mushola; site plan of Notobratan/ Kasepuhan (source: Survey, 2017) 

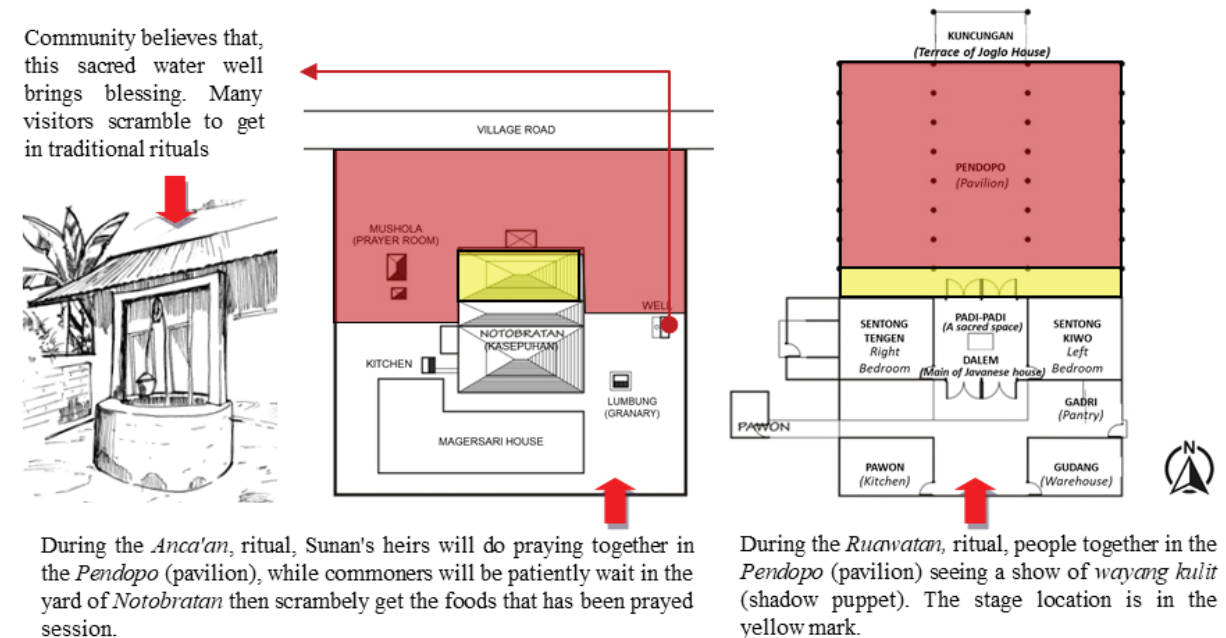

During the Ruawatan, ritual, people together in the Pendopo (pavilion) seeing a show of wayang kulit (shadow puppet). The stage location is in the yellow mark.

Figure 10. The using of space in traditional rituals of Sunan Kalijaga (source: Survey, 2017)

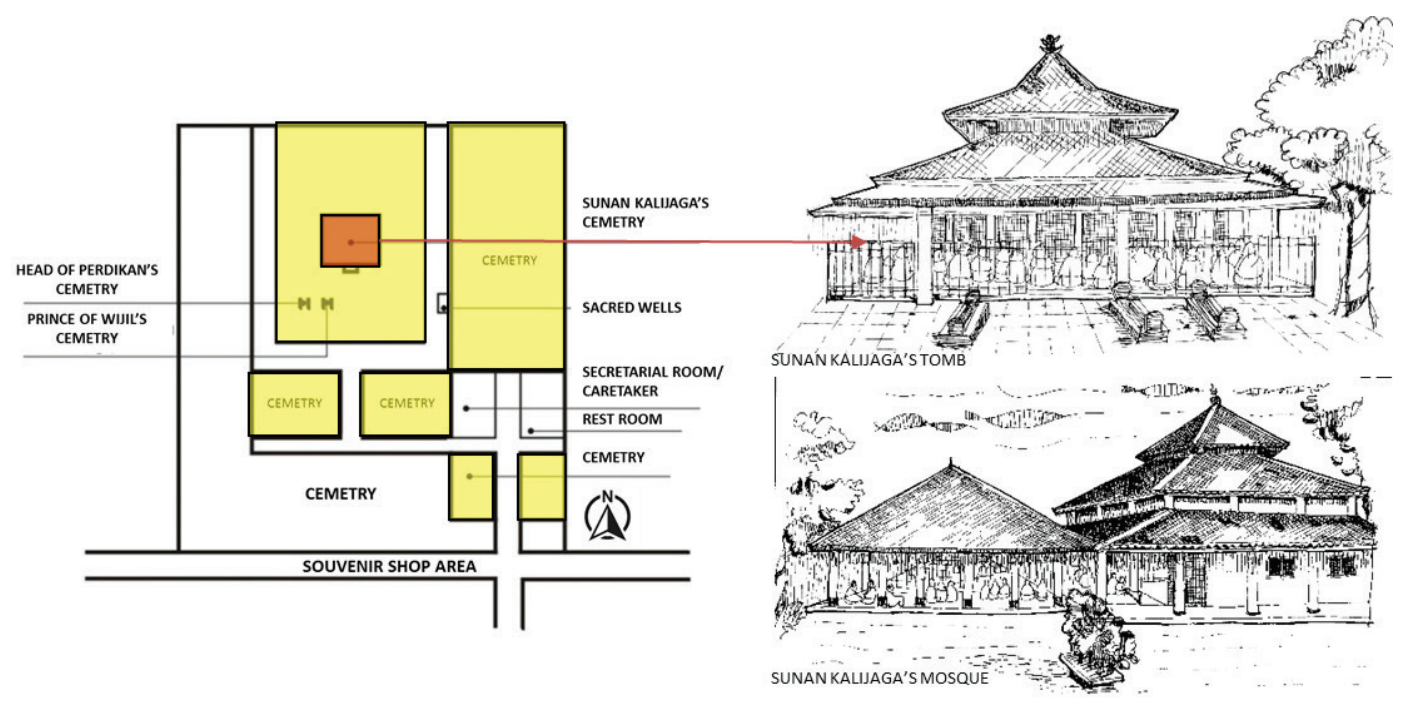

Figure 11. Some sacred seats in the traditional ritual of Sunan Kalijaga's cemetery (left), (right) above is Sunan Kalijaga's tomb and below is Sunan Kalijaga's mosque (source: Survey, 2017)

the fenceless row buildings. These houses create friendly neighborhood. Shawl house forms also create high social cohesion among neighbors (See Figure 12). The phenomenon of shawl houses show spatial adaptation of residence influenced by social and economic conditions in addition to the activities and life style as the driving factors. However, this study found that the local belief serves as the retaining factor.

\subsubsection{Toward a creative economy}

The site of Kadilangu has been developed into a local religious tourism destination since 1999, which has contributed to people's prosperity; hence it significantly increase business spaces near the cemetery and in the residence areas. This is a capitalization of spaces that possess economic value or valuable commodities, and mobilizes capital as

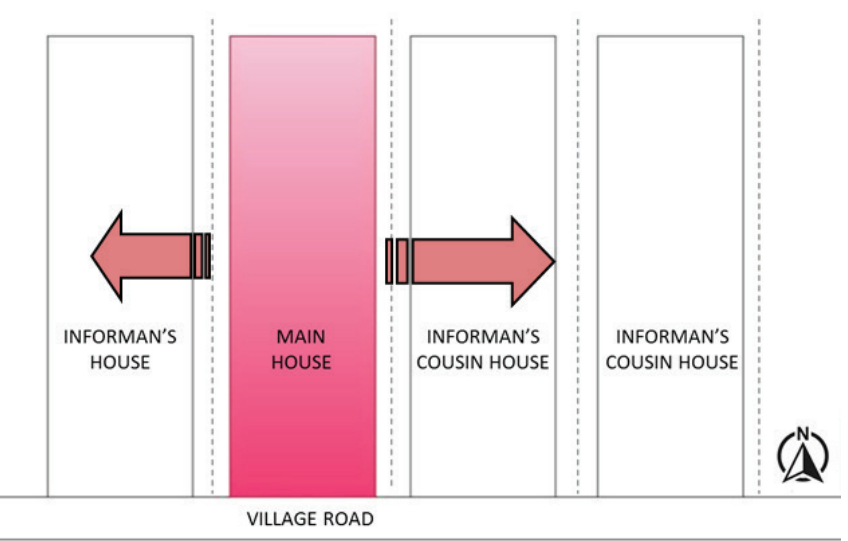

Figure 12. The shawl house form (source: Survey, 2017) 
well as labors (Lefebvre, 1991). Businessman come from people of magersari and others surrounding villages. The prominent products of creative ideas include batik, which is a traditional fabric, and gendang - a traditional music tool made from wood and leather. This business is in connection with the creative economy involving public participation because the craftworks are from the local idea's creativity (Howkins, 2001). Although the creativity still in the early phase, it has a potential since this area has been developed into the tourism destination. The change of space caused by tourism activities allows the emergence of creative economy based on local culture. The existence of the business space presses to the setting of private spaces. Some of characters are described below.

\section{Mixed use houses}

Many houses around the mosque and the cemetery functioned as a business ventures supporting facilities for tourism. For example, there are home stay, home industry of batik craft, a traditional music tool of gendang craft, souvenir shop, and so on. In addition, many front yards are converted into shops (see Figure 13).

\section{Using fixed and semi fixed feature elements of space}

Many houses change in the spatial arrangement to accommodate the changing use of building for business ventures such as home stay, show room, shop house, production house of craft. The inhabitants use fixed feature elements, such as a brick wall, and semi fixed feature elements, such asfurnitures. This is manifestation of space requirements on the basis of people creativity against the limited space by using fixed and semi fixed feature elements (Hall, 1996; Rapoport, 1990, 2000). This research showed the existence of flexible space that effectively accommodates the needs of both domestic and external spaces.

\subsubsection{Change due to tourism development}

\section{Change of space}

The change of space due to tourism development can be classified into three categories: 1) the addition of spaces for economic activities; 2 ) the change of vernacular houses into modern buildings for business; 3 ) the additional of function of a house (as the main residence and the place for souvenir craft). The changes occur spontaneously depending on their financial condition. The specific change of houses is related to the vertical development. It is prohibited to develop buildings higher than the Sunan's tomb.

Changes that also appear on the open space are: 1) the functional change of an outdoor area, such as a field transformed a parking lot; 2) the change in shape and function, such as the transformation of an open space into housings and tourism facilities; 3 ) the desecration in segaran (a pond inside the complex of Sunan site to conduct some ritual ceremonies), which was a sacred bath converted into a public tourism spot (see Figure 14). The decrease in open spaces due to some buildings. From description above, it shows that some changes occurred in regards to functions and spaces arrangement as a result of social - economic activity, and lifestyle. Some of sacred values still exist with respect to the sanctity of Sunan, but others have turned into propane as Segaran. This indicates that identity of the area is still sufficiently maintained by vertical building settings, instead of horizontal setting.

\section{Impacts for community}

The escalation of economic activities of cultural tourism both formal and informal increases the welfare of the community around the site by providing employment for inhabitants especially housewives. Formal education and skills of the population improve along with community empowerment. Changes occurred in the houses functionally, spatially, technologically. The economic benefits
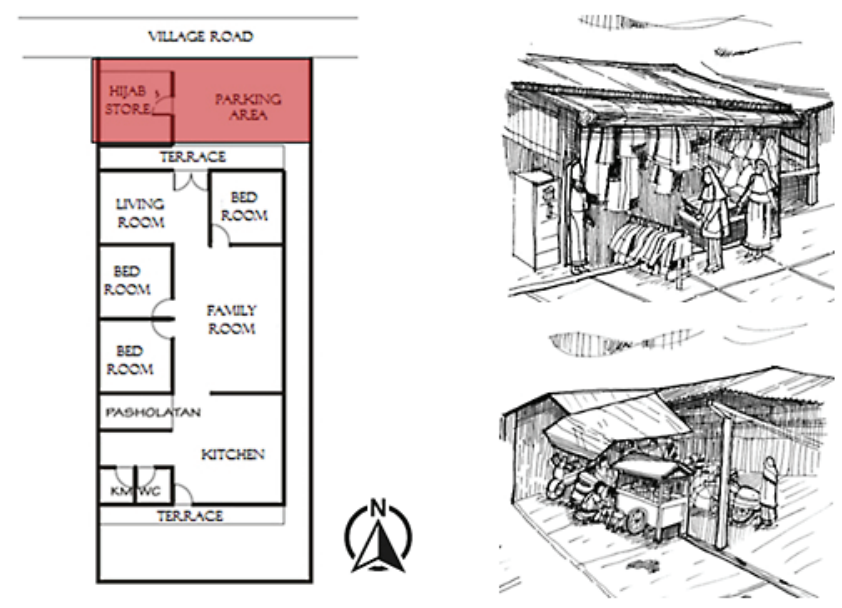

Change of function of living houses to be business ventures like souvenir houses close to the mosque and the cemetery

Change of front yard houses function is visible. former it used to be a social space, but now is using for an economic space, some for parking lots.

Figure 13. The change of houses function into economic space (source: Survey, 2017) 


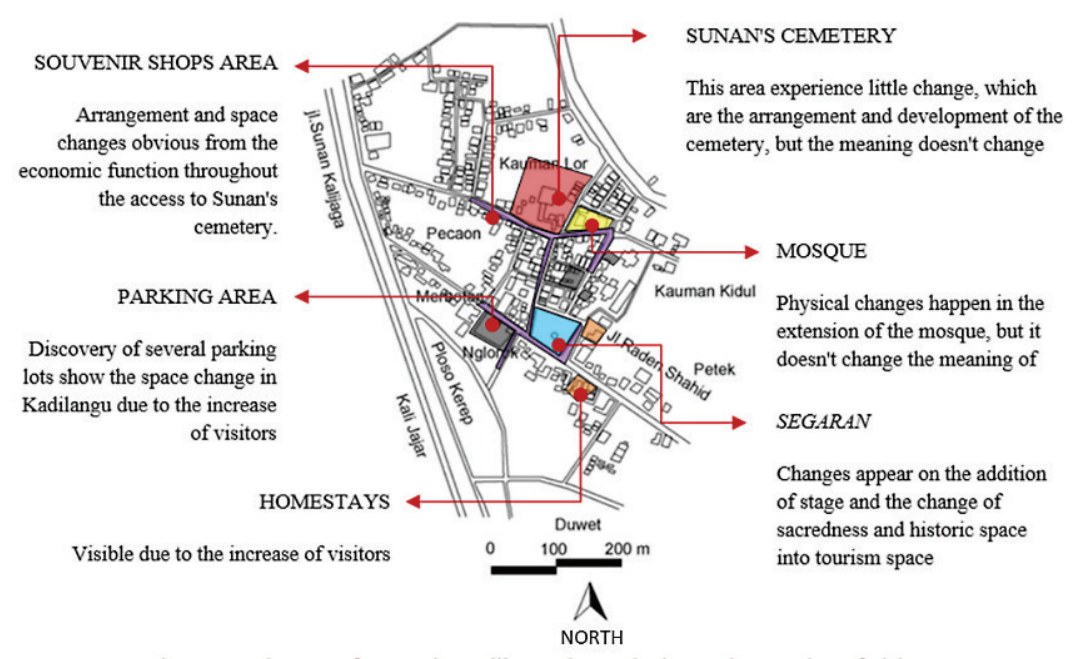

Figure 14. Changes of spaces in Kadilangu due to the increasing number of visitors (source: Survey, 2017)

of investment in cultural heritage appear as public goods (Chauhan, 2017), which have an effect on the increase of private goods, as well as the quality improvement of life of the community life. The concomitant result is the lack of local friendly culture that is replaced by the modern culture - individualist and capitalist. The social environment is prone to crime due to the increasing number of outsiders.

\subsection{Space for moral control}

\section{The Role of Pondok Pesantren}

Pondok Pesantren is a traditional Islamic boarding school established in 1881 by Kyai (local religious leaders) to teach Islam to the young generations. During its development process, pesantren bought and built the land gradually. The facilities of pesantren include male dormitory, female dormitory, secretariat office, and mushola (prayer area). Within this religious education system the young generations mentality of Kadilangu village and its surroundings are controlled by community organization, this is similar to the statement of Lughod (1987). Religious education is a controlling tool for social change of a community (Ishomuddin, 2005; Suprapti et al., 2016).

2. Symbiosis Space

Some facilities are found inside the pesantren complex include mosque, classrooms and dorms for santri (student of pesantren). These buildings are open for people living in surrounding areas. Kyai and other members of pesantren have a good chance to build relationship with public in which pesantren facilitates public to participate in the future development. The most obvious space symbiosis is the mosque used by both santri and the local residents. It shows the use of resources that will provide a positive impact on the effectiveness and efficiency of spatial arrangement, especially in rural areas, the same condition was stated by Wang, Fei, Ye, and Zhang (2014).

\section{Segregation of Gender}

Segregation of gender can be seen in the use of public facilities like classrooms, mosque, hall, etc. Islamic teaching limits direct contact of opposite gender in order to protect women. The distantly located buildings strengthen the gender separation. Male spatial activities are more widely radiated while female spatial activities are mostly centered inside the building. Refering to Lughod (1987), this separation is the form of implementation of the Muslim norms protecting and appreciating females to encourage gender segregation.

\section{Conclusions}

Both tangible and intangible cultures found in this research are the social capitals to support a creative city. These potencies are in the form of: (1) cemetery artifacts and buildings, (2) the authenticity of local cultural space settings, (3) the authenticity of the population, (3) the ongoing rituals, (4) the public trust, (5) the community participation in the form of economic creativity.

The factors influencing the development of Kadilangu includes: (1) the Islamic-Javanese religious teaching that becomes the filler in the culture of Kadilangu, (2) the aristocratic Javanese-Islam culture in Kadilangu area has been created a character of Kadilangu place, and (3) the economy of religious tourism, which has been growing rapidly, as a significant potential area.

This research found three concepts of spaces that are:

- Identity Spaces. This is the existential symbol of the descendants of Sunan Kalijaga although the degradations have occurred in the functions of shapes.

- Spaces for commoners developed around the mosque and the cemetery. The symbol of commoners' existence in the Kadilangu has grown stronger since the tourism improves. Creative economy starts to grow, 
even though assistance to the community is important to share ideas and motivate the local community.

- Spaces for morality education. The existence of pesantren is needed to control the public morality. Pesantren facilitates the sharing of infrastructures in the surrounding community that makes the spatial planning can be more effective and efficient.

The place of Kadilangu as a local culture heritage is a potential tourism asset. Meanwhile the supports from public in the form of creative economy are necessary. For further research, it is advisable to look for an appropriate model of spatial planning for community based on sustainable development to accommodate socio-cultural, tourism economics, and ecological aspects.

\section{Acknowledgements}

The Authors would like thank to Prof. Dr. Heru Susanto (the Head of Research and Community Service Institution Chairman of Diponegoro University), M. Agung Wibowo, PhD (the Dean of Engineering Faculty of Diponegoro University), Meta Khairunisa, Kania Kinasih, Nurma Mediasri, Benz Adi Akbar, colleagues, informants, and all parties for their assistance during the research process. This research was financially supported by the General Directorate of Higher Education of Republic of Indonesia.

\section{References}

Agustina, I. H., et al. (2014). Kajian Makna Ruang Tradisi Esoterik Kawasan Keraton Kasepuhan Cirebon [Study of Esoteric Tradition of Keraton Area Kasepuhan In Cirebon]. Prosiding SNaPP 2014 Sains, Teknologi, dan Kesehatan. Bandung: Unisba.

Amerta, I. (2017). The role of tourism stakeholders at Jasri Tourism Village development Karangasem regency. International Journal of Social Sciences and Humanities, 1(2), 20-28. https://doi.org/10.29332/ijssh.v1n2.32

Chauhan, E. (2017). Social and economic impact of heritage conservation in Delhi: Case studies of Shahjanabad and Nizamudinn Basti (dissertation for study of social exclusion and inclusive policies national law school of India university Bengaluru). India.

Dewi, C. (2017). Rethinking architectural heritage conservation in post-disaster context. International Journal of Heritage Studies, 587-600.

https://doi.org/10.1080/13527258.2017.1300927

Dundar, O. (2001). Models of urban transformation, informal housing in Ankara. Cities, 18(6), 391-401. https://doi.org/10.1016/S0264-2751(01)00031-2

Ekomadyo, A. S. (1999). Tesis Kajian "Kota Islam" Penelusuran Kaitan Antara Ide-ide Kota dalam Sumber Hukum Islam dengan Pola Tata Letak Fisik Perkotaan yang Ada Study [Thesis of "Islamic City" Searching the Linkages Between City Ideas in Sources of Islamic Law with Existing Urban Physical Layout Patterns]. Bandung: Program Magister Arsitektur ITB.

Habraken, N. J., et al. (1976). Variations, the systematic design of supports. Cambridge: MIT Press.

Hall, E. T. (1996). The hidden dimension. McGraw-Hill.

Higgins, P. (2014). Quality of life and spatial inequality in London. European Urban and Regional Studies, 21(1), 42-59. https://doi.org/10.1177/0969776412439201
Howkins, J. (2001). The creative economy: How people make money from ideas. London: Penguin Kellet.

IPCC. (2014). Climate change. Mitigation of climate change 2014. Retrieved from https://www.ipcc.assessment.report

Ishomuddin, S. A. (2005). Sosiologi Perspektif Islam [Islamic Perpective Sociology]. Malang: Universitas Muhamadiyah.

Keller, W. (2002). Geographic localization and international technology diffusion. American Economic Review, 92, 120142. https://doi.org/10.1257/000282802760015630

Koenjtaraningrat. (1983). Kebudayaan Mentalitas dan Pembangunan [Culture, mentality and development]. Jakarta: PT Gramedia.

Laukonnen, J., Blanco, P., Lenhart, J., Keiver, M., Carvic, B., \& Kinuthja-Njenga, C. (2009). Combining adaptation and migitation measures at the local level. Habitat International, 33, 287-292. https://doi.org/10.1016/j.habitatint.2008.10.003

Lawanson, T., et al. (2012). An investigation of rural-urban linkages of the Lagos Megacity, Nigeria. Journal of Construction Project Management and Innovation, 464-581.

Lefebvre, H. (1991). The production of space. Oxford UK: Blackwell; USA: Cambridge.

Linton, R. (1956). The tree of culture. New York: Alfred A. Knopf. Lombard, D. (2005). Nusa Jawa: Silang Budaya, Kajian Sejarah Terpadu, Bagian II: Jaringan Asia [Java Island: Cross-Culture, Integrated History Study, Part II: Asia Network]. Jakarta-Paris: PT Gramedia Pustaka Utama.

Lughod, A. L. J. (1987). The Islamic city: historic myth, Islam essence and contemporary relevance. International Journal of Middle East Studies, 19(02), 155-176. https://doi.org/10.1017/S0020743800031822

Marlina, A. (2017). Residential space transformation as the legitimacy space a case study: Magersari Ndalem Sasanamulya Baluwarti Sunanate Palace Of Surakarta. IOP Conference Series: Earth and Environmental Sciences, 213 (2018), 012013.

Moedjanto, G. (1987). Konsep Kekuasaan Jawa Penerapannya oleh Raja-raja Mataram [The Concept of Javanese Power Its Application by the Kings of Mataram]. Yogyakarta: Penerbit Kanisius.

Moertono, S. (1985). Negara dan Usaha Bina Negara di Jawa Masa Lampau [The Country and Business of Developing Countries in Old Java]. Jakarta: Yayasan Obor Indonesia.

National Research Council. (2010). Adapting to the impacts of climate change. The National Academic Press.

Qurtuby, S. A. (2003). Arus Cina-Islam-Jawa [Chinese-MuslimJavanese Flow]. Yogyakarta: Inspeal Ahimsakarya Press.

Rapoport, A. (1969). House form and culture. Englewood Cliffs, NJ: Prentice Hall.

Rapoport, A. (1990). The meaning of the built environment: A nonverbal communication approach. Tucson: University of Arizona Press. Arizona.

Rapoport, A. (2000). Theory, culture, and housing. Housing, Theory and Society, 17(4), 145-165. https://doi.org/10.1080/140360900300108573

Rapoport, A. (2005). Culture, architecture, and design. Chicago, IL: Locke Science Publishing.

Rossi, A., \& Eisenman, P. (1982). The architecture of the city. The MIT Press.

Santoso, J. (2013). Memahami Transformasi Urban di Asia: Belajar dari Kasus Jakarta [Understanding Urban Transformation in Asia: Learning from Jakarta Case]. Tata Loka, 15(2), 102. https://doi.org/10.14710/tataloka.15.2.102-115

Setiadi, A. (2006). Disertasi: Persistensi Pola \& Tipe Jalan di Kampung Dalem (Dissertation) [Persistence of patterns and road types in Dalem Village]. Bandung: Universitas Katolik Parahyangan. 
Spradley, J. P. (1997). Mengamati Sambil Ikut Serta Metoda Observasi Partisipatif [Observing while participating in participatory observation methods]. Yogyakarta: Pusat Pastoral.

Suprapti, A., et al. (2010). Ethnography-architecture in Kampong Kauman Semarang, A comprehension of cultural toward space. American Journal of Engineering and Applied Sciences, 3(3). https://doi.org/10.3844/ajeassp.2010.576.587

Suprapti, A., et al. (2014). The tradition of living of Muslim community Kudus Kulon. Journal of Social Sciences, 10(2). https://doi.org/10.3844/jssp.2014.63.73

Suprapti, A., et al. (2016). The urban heritage of Masjid Sunan Ampel Surabaya, toward intelligent urbanism development. Proceedia - Social and Behaviour Sciences, 227, 601-608.

Sutrisno, M., \& Putranto, H. (2005). Teori-teori Kebudayaan [Theories of Culture]. Yogyakarta: Penerbit Kanisius.

Syafi'i, M., et al. (2015). Tourism village planning concept approach community based tourism [Case Study: Bedono Village, Sayung, Demak]. Ruang, 1(2), 51-60.
Tjandrasasmita, U. (2000). Pertumbuhan dan Perkembangan Kota-kota Muslim di Indonesia [The Growth and Development of Muslim Cities in Indonesia]. Kudus: Penerbit Menara Kudus.

Wang, C., Fei, Z., Ye, Q., \& Zhang, Y. (2014) Rural settlement space reconstruction strategy and implementation based on symbiosis theory on village scale. Transactions of Chinese Society of Agricultural Engineering, 30(3), 2015-214.

Wertheim, W. (1999). Masyarakat Indonesia dalam Transisi [Indonesian Society in Transition]. Jakarta: PT Gramedia Pustaka Utama.

Wiryotomo, A. B. (1995). Seni Bangunan dan Seni Binakota di Indonesia [Art of Building and Cities Development in Indonesia]. Jakarta: PT Gramedia Pustaka Utama.

Zahnd, M. (2006). Perancangan Kota Secara Terpadu [Integrated City Planning]. Yogyakarta: Kanisius.

Bappeda Demak. (2015). Rencana Umum Tata Ruang Kota Demak [General Plan for City Spatial Planning]. Demak: Bappeda Demak. 